Avaliable online at http://e-journal.unipma.ac.id/index.php/gulawentah

\title{
PENINGKATAN AKTIVITAS DAN PEMAHAMAN KOLONIALISME EROPA DI INDONESIA MELALUI MODEL MAKE A MATCH PICTURE PADA SISWA KELAS VII SMPN NGEBEL PONOROGO
}

\author{
Rias Susilowati \\ SMPN 1 Ngebel Ponorogo \\ Email: watirias@gmail.com
}

\begin{abstract}
Abstrak
Penelitian ini bertujuan untuk meningkatkan aktivitas dan pemahaman siswa kelas VII SMPN Ngebel Ponorogo terhadap pemahaman kolonialisme Eropa di Indonesia melalui penerapam model make a match picture. Pendekatan penelitian menggunakan penelitian kelas sebanyak dua siklus dengan subyek penelitian siswa kelas VII B. Pengambilan datanya dengan tes, observasi, dan wawancara, serta dianalisis kualitatif interaktif. Hasil dari ulangan harian khusus kelas ini $73 \%$ belum bisa mencapai ketuntasan. Mengingat pentingnya pemahaman yang benar terhadap materi IPS ini, kami menemukan langkah yang sesuai antara materi dengan model pembelajarannya, yaitu Make A Match Picture. Ternyata ada peningkatan, baik aktifitas maupun pemahaman. Aktifitas pada siklus I $88 \%$ (target $76 \%$ ), siklus II menjadi 100\%, sedangkan pemahaman walau baru $61 \%$ dan belum mencapai target yaitu $76 \%$, tapi pada siklus II meningkat menjadi menjadi 84\% (targetnya 80).
\end{abstract}

Kata kunci: aktivitas, model make a match picture, pemahaman

The Improvement of Activities and Understanding of Europe Colonialism in Indonesia through Make a Match Picture Model for the Seventh Grade Students of SMP Ngebel Ponorogo

\begin{abstract}
The study aims to improve activities and understanding of Europe colonialism in Indonesia through Make a Match Picture model for the seventh grade students of SMP NgebelPonorogo. This action classroom research executed two cycles, with using class VII B as the subject of the study. Data were collected through test, observation, and interviews. The data, then, were analyzed using interactive qualitative. Score of formative test of class VII B has not achieved the target score yet. Regarding the importance of the material in Social Science, it is necessary to provide a way of adjusting the material and the learning model, that it isMakea Match Picture. The results show that there is an improvement of both students' activities and understanding. In cycle I, the students' activities achieve at $88 \%$ (of the target level at $76 \%$ ), they become $100 \%$ in the cycle II. Meanwhile, the students' understanding only reaches at $61 \%$ and it has not reached the target level of $76 \%$ in the cycle I. Later, it increases at $84 \%$ (of the target level at $80 \%$ ) in the cycle II.
\end{abstract}

Keywords: activities, make a match picture model, understanding

\section{Pendahuluan}

Mempelajari Ilmu IPS diperlukan pemahaman yang benar, mengingat materi yang terkandung dalam IPS begitu luas. sampai akhirnya peserta didik SMP akan memiliki pemahaman dan wawasan positif dalam mempelajari peristiwa-peristiwa sosial, tanggap dan peka terhadap masalah-masalah sosial, serta mampu memecahkan masalah- 
Avaliable online at http://e-journal.unipma.ac.id/index.php/gulawentah

masalah sosial serta memiliki pandangan positif terhadap pemecahan masalahmasalah sosial baik yang menyangkut diri sendiri maupun orang lain. Begitu juga pada materi Kolonialisme Eropa di Indonesia yang menyangkut berbagai peristiwa perdagangan internasional sampai akhirnya terjadi penjajahan bangsa Eropa di Indonesia.

Berkaitan dengan hal tersebut dan juga terinspirasi dari Dimyati, Mudjiono (2015 : 248) menyampaikan bahwa pengajar yang mendidik. Ia tidak hanya mengajar bidang studi yang sesuai dengan keahliannya, tetapi juga menjadi generasi pendidik bangsanya. Sebagai pendidik, ia memusatkan pada kepribadian siswa, khususnya berkenaan dengan kebangkitan belajar. Kebangkitan belajar tersebut merupakan wujud emansipasi siswa. Sebagai guru yang mengajar, ia bertugas mengelola kegiatan belajar di sekolah". Maka perlu lebih kreatif dalam upaya meningkatkan aktifitas dan pemahaman peserta didik, beberapa pemecahan masalah diantaranya peneliti mencoba model pembelajaran, "Make a Match Picture", yaitu dengan sistem kartu berpasangan bergambar, kartu berupa gambar tentang Kolonialisme di Indonesia dan kartu yang lain berupa jawaban/ penjabaran konsep. Model sederhana dan mudah dibuat, serta sesuai benar dengan peserta didik.

Untuk itu pembuatan kartu sebaiknya disesuaikan dengan jumlah peserta didik, kelas peneliti berjumlah 26. Berarti diperlukan 13 kartu berupa kartu gambar dan 13 kartu berupa konsep atau penjelasan singkat dari gambar pasangannya. Model pembelajaran ini melibatkan peserta didik dalam satu kelas aktif. Setelah melalui pengamatan dan menggali informasi, masing-masing peserta didik akan mencari pasangannya untuk mencocokkan antara gambar dengan konsep atau penjelasannya Salah satu tujuan pendekatan CTL adalah menempatkan peserta didik sebagai subyek belajar, yang berarti peserta didik berperan aktif dalam setiap proses pembelajaran dengan cara menemukan dan menggali sendiri materi pelajaran, bukannya menerima informasi secara pasif". Untuk lebih menekankan pada proses belajar bukan mengutamakan hasil belajar, mencoba menerapkan Pendekatan Kontekstual dengan model pembelajaran "Make a Match Picture" ini pada pembelajaran tentang masa Kolonialisme Eropa di Indonesia pada mata pelajaran IPS kelas VII.

Untuk itu perlu diberi stimulus (rangsangan) sehingga peserta didik akan bergairah untuk belajar, yang nantinya mengarah pada peningkatan aktifitas dan pemahaman belajar peserta didik pada materi tentang Kolonialisme di Indonesia sehingga hasil belajarnya juga akan meningkat.

Peserta didik berada di daerah pinggiran yang perlu sekali menerima hal baru untuk menciptakan suasana yang betul-betul kondusif dalam proses pembelajaran sesuai dengan perkembangan taraf berfikirnya. Menyiasati kadang-kadang listrik mati mendadak, apalagi jika musim penghujan, sehingga kreatifitas perlu untuk menambah proses pembelajaran semakin enjoy. Dengan harapan nantinya bisa semakin meningkat 
Avaliable online at http://e-journal.unipma.ac.id/index.php/gulawentah

aktifitas dan pemahamannya tehadap materi IPS.

Dalam proses penelitian ini peneliti didampingi observer atau pengamat dari sesama mata pelajaran IPS yaitu Yudi Astomo (mengajar IPS kelas VIII), dengan tujuan lebih mudah untuk memahami dan mengamati selama proses pembelajaran. Seperti pendapat Sanjaya (2015:78), "Peran kolaborasi sangat menentukan keberhasilan PTK. Kolaborasi dilakukan dalam setiap kegiatan, misalnya merumuskan masalah, menyusun usulan atau proposal penelitian, melaksanakan PTK utu sendidr sampai menyusun laporan penelitian". Dengan didampingi pengamat akan memperkuat kevalidan data hasil selama proses penelitian. Sebagai bahan pertimbangan lainnya bahwa di sekolah ini, guru IPS adalah berjumlah 3 orang. Sehingga memerlukan bantuan guru sesama mata pelajaran sebagai patner atau mitranya.

Pengalaman selama menerapkan make a match yang diisi berupa tulisan tanpa gambar sudah membuat peserta didik suka dan aktif terlibat selama proses pembelajaran. Tentu dengan ditambah gambar membuat peserta didik lebih antusias mengikuti Penelitian ini bertujuan untuk: (1) Menerapkan model pembelajaran "Make a Match Picture" pada peserta didik untuk meningkatkan aktifitas dan pemahaman pada materi Koloniaisme Eropa di Indonesia, (2) Menerapkan model pembelajaran 'Make a Match Picture" pada peserta didik untuk mengetahui kendala dan kemudian mencari solusi pada materi Koloniaisme Eropa di Indonesia dalam proses pembelajaran.
Dalam Kamus Besar Bahasa Indonesia (2008:1529) bahwa arti kata peningkatan proses, cara, perbuatan meningkatkan (usaha, kegiatan, dsb). Sedangkan pemahaman (insight) merupakan pemecahan masalah secara tiba-tiba tanpa lebih dulu melewati upaya trial and error (coba dan salah), merupakan seseorang yang memiliki intuisi yang sangat tajam; (understanding), proses menjadi tahu hubungan antar hal yang berarti hasil yang telah difikirkan, diupayakan, dicapai, dilakukan, dikerjakan dan sebagainya.

\section{Metode Penelitia}

Penelitian ini mengunakan rancangan penelitian tindakan kelas (classroom action research). Penelitian ini dilaksanakan dua siklus, masingmasing terdiri dari empat langkah, yaitu: a). Perencanaan, b) tindakan, c) observasi, dan d) refleksi. Dari hasil observasi, peneliti merefleksi dengan menganalisis data dari hasil observasi kegiatan yang dilakukan. Ditemukan kekurangan dan kelebihan, hasil analisis data akan digunakan sebagai acuan untuk melaksanakan siklus kedua.

Subyek penelitian adalah peserta didik kelas VII B tahun pelajaran 2015/2016, jumlah peserta didik ada 26. Perlu diketahui pula bahwa SMP Negeri 1 Ngebel mempunyai 399 peserta didik, dengan 18 kelas rombongan belajar, tenaga pengajar berjumlah 34 orang guru, 6 orang tenaga administratif, 1 orang petugas perpustakaan (Kepala Perpustakaan adalah Guru Bahasa Indonesia), 1 orang penjaga, dan 1 orang kepala sekolah. Peneliti melibatkan 
Avaliable online at http://e-journal.unipma.ac.id/index.php/gulawentah

seorang kolaborator sebagai mitra dalam penelitian ini.

Teknik pengumpulan data dalam pelaksanaan penelitian ini ada dua macam yakni: (a). Data primer (Data kemampuan awal peserta didik) dan Data tentang pelaksanaan pembelajaran, (b). Data sekunder adalah data tentang aktivitas peserta didik, dan data tentang hasil postest (UH) peserta didik. Sedangkan data-data akan dapat diperoleh dengan menggunakan alat pengumpul data sebagai berikut: (a). Observasi (pelaksanaan proses pembelajaran ketika sedang berlangsung), (b). Dokumentasi (hasil pemotretan peserta didik selama proses pembelajaran berlangsung dan kumpulan dari hasil ulangan dalam siklus).

\section{Hasil dan Pembahasan}

Dalam pelaksanaan penelitian ini, evaluasi juga dilaksanakan secara bersama-sama dengan guru pendamping selaku anggota tim penelitian. Pada siklus I belum bisa diperoleh hasil maksimal, tetapi sudah ada peningkatan yang diperoleh oleh 12 peserta didik $46 \%$ atau jika dihitung keseluruhan ada $\pm 61 \%$ (kurang dari target, yaitu $76 \%$, dan ada yang mengalami penurunan 10 peserta didik. Kegiatan ini dilakukan untuk menemukan sesuatu atau temuantemuan baru yang perlu dipecahkan. Adapun yang perlu dilakukan pencatatan dalam pelaksanaan siklus I antara lain: 1). Peserta didik masih kelihatan masih bingung mencari pasangan kartunya, sehingga sampai batas waktu ada dari beberapa peserta didik yang belum mendapatkan pasangannya.
Sebagian mendapatkan tetapi belum tepat, 2). Ketidak sesuaian dan ketidaktepatan dikarenakan belum memahami materi sepenuhnya dan aturan permainannya. Walaupun sebenarnya sudah dilakukan 2 kali putaran, 3). Jika melihat dari peningkatan hasil, penelitian ini bisa dilanjutkan ke siklus II. Dengan dilanjutkan ke siklus II diharapkan ada kenaikan di atas $80 \%$. Untuk mengevaluasi hasil pelaksanaan siklus I secara keseluruhan hendaknya keberhasilan siswa seimbang antara kegiatan kelompok dan ulangan mandiri.

Untuk itu masih perlu peningkatan dalam beberapa hal, antara lain: 1). Agar lebih mudah perlu lebih dalam mengamati gambar untuk kartu, 2). Jumlah siswa yang mendapat nilai meningkat, dari hasil diskusi kelompok sudah menunjukkan adanya kerjasama walaupun nilainya belum seluruhnya bagus. Tapi kegiatan mengamati dan mencari pasangan kartu membuat anak lebih semangat dlam kegiatan pembelajaran, 3). Berarti dalam siklus I menandakan bahwa penerapan Model Pembelajaran Make A Match Picture ada peningkatan prestasi belajar, maka perlu dilanjutkan pada siklus II. Peserta didik perlu kejelian dalam mencari pasangan kartunya untuk memperoleh ketepatan pasangan kartunya, perlu mengulang kembali permainan kartunya dengan tujuan semua peserta didik benar-benar memahami dan sampai akhirnya bisa mencocokan pasangan kartu dengan tepat.

Pada siklus II sudah bisa diperoleh hasil maksimal dan banyak peningkatan yang diperoleh oleh peserta didik. 
Avaliable online at http://e-journal.unipma.ac.id/index.php/gulawentah

Adapun yang peningkatan-peningkatan yang dilakukan dalam pelaksanaan siklus II antara lain: 1). Peserta didik sudah lancar mencari pasangan kartu dan lebih baik dalam membaca hasil membaca kartu berpasangan dan sudah lebih baik intonasinya, 2). Peerta didik sudah leluasa untuk memperkirakan atau mudah membanding-bandingkan dalam proses mencari dan menemukan, 3). Pembagian kelompok benar-benar adil (kemampuan antar kelompok seimbang).

Perubahan antara sebelum tindakan dan setelah dilakukan tindakan jelas perbedaannya, apalagi bila dilihat perbandingan hasil antara siklus I dan II menunjukkan angka yang menggembirakan. Berarti model pembelajaran kartu make a match picture bisa meningkatkan aktifitas dan pemahaman peserta didik khususnya kelas VII B Tahun Pelajaran 2015/2016. Dan pada siklus II ini sudah menunjukkan hasil baik, yang berarti semua peserta didik sudah bisa meningkatkan aktifitas dan pemahamanya tentang materi tersebut. Walaupun nilai tidak semuanya bagus, karena ada pengaruh terpenting yang tidak bisa kita ubah yaitu kemampuan awal siswa. Agar data yang diperoleh pada penelitian mudah dilihat dan dapat diketahui perkembangannya pada hasil sebelum tindakan, siklus I maupun siklus II, akan peneliti sajikan rekapitulasinya secara terperinci pada tabel sebagai berikut:

Tabel 1. Rekapitulasi Jumlah Peserta Didik Dalam Perolehan Skor Aktifitas Permainan Kartu antara Siklus I dan II

\begin{tabular}{cccccc}
\hline \multirow{2}{*}{ No } & \multirow{2}{*}{$\begin{array}{c}\text { Sentang } \\
\text { Skor }\end{array}$} & Prasiklus & Siklus 1 & Siklus 2 & \multirow{2}{*}{ Keterangan } \\
\cline { 3 - 5 } & $0-39$ & & 2 & 1 & Krg \\
\hline 1 & $40-65$ & 6 & 1 & Krg \\
\hline 2 & & 3 & 0 & Ckp \\
\hline 3 & $66-75$ & 7 & 13 & B \\
\hline 4 & $76-85$ & 8 & 11 & B Skl \\
\hline 5 & $86-100$ & & 26 & 26 & \\
\hline Jumlah Siswa & $\begin{array}{c}\text { Belum } \\
\text { Tindakan }\end{array}$ & & & & \\
\hline
\end{tabular}

Tabel 2. Perbandingan Jumlah Peserta Didik Dalam Perolehan Nilai Ulangan Harian Pada Pra Siklus, Siklus I dan Siklus II

\begin{tabular}{cccccc}
\hline No & $\begin{array}{c}\text { Rentang } \\
\text { Skor }\end{array}$ & \multicolumn{3}{c}{ Ulangan Harian } & \multirow{2}{*}{ Keterangan } \\
\cline { 3 - 5 } & Prasiklus & Siklus 1 & Siklus 2 & \\
\hline 1 & $30-39$ & 9 & 2 & - & Krg \\
\hline 2 & $40-65$ & 7 & 13 & 4 & Krg \\
\hline 3 & $66-75$ & 3 & 7 & - & Ckp \\
\hline 4 & $76-85$ & 4 & - & 9 & B \\
\hline 5 & $86-100$ & 3 & 4 & 13 & B Skl \\
\hline Jumlah Siswa & 26 & 26 & 26 & \\
\hline
\end{tabular}

Secara jelas dan lebih mudah diketahui perkembangan jumlah peserta didik yang memiliki aktifitas bermain kartu baik pada siklus I maupun II ada 
Avaliable online at http://e-journal.unipma.ac.id/index.php/gulawentah

pada tabel 1. Pada tabel tersebut terlihat ternyata peserta didik antuas dalam bermain kartu dan ingin mengulang kembali pada siklus II, peserta didik ingin mendapat giliran dari semua pasangan kartu. Sedangakan yang memperoleh nilai dalam setiap kategori, dapat dilihat pada tabel 2. Sedangakan yang memperoleh nilai dalam setiap kategori, dapat dilihat pada Gambar ini
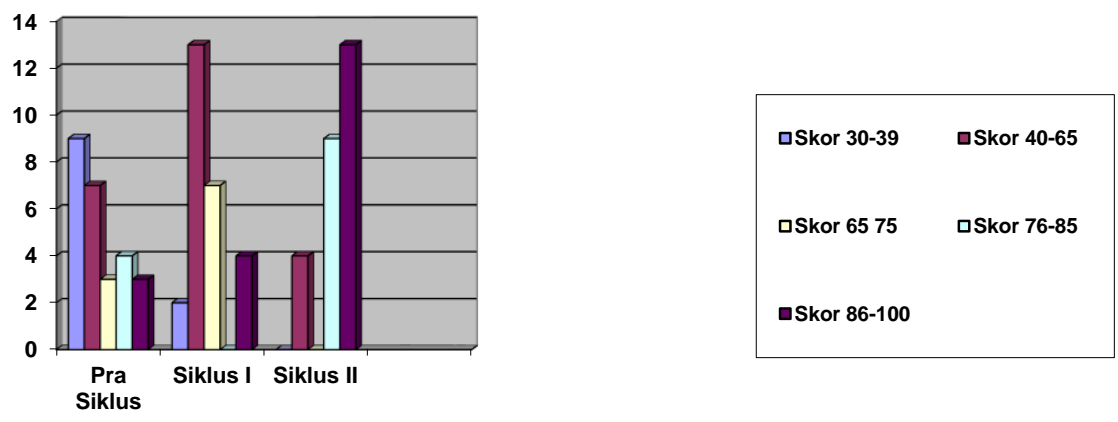

Gambar 1. Perbandingan nilai siswa pra siklus, siklus I dan siklus II

Berdasarkan gambar grafik di atas pada Prasiklus peserta didik yang mendapat nilai tes akhir dalam kategori:

1. Kurang adalah 16 peserta didik.

2. Cukup adalah 3 peserta didik.

3. Baik adalah 4 peserta didik.

4. Baik sekali adalah 3 peserta didik.

Pada pra siklus peserta didik yang tuntas ada 7 atau $27 \%$.

Berdasarkan grafik di atas pada Siklus I siswa yang mendapat nilai tes akhir dalam kategori:

1. Kurang adalah 15 peserta didik.

2. Cukup adalah 7 peserta didik.

3. Baik adalah 0 peserta didik.

4. Baik sekali adala 4 peserta didik.

Pada siklus I peserta didik yang tuntas baru ada 4 peserta didik atau $15 \%$ (KKM 76). Pada siklus I ini yang tuntas menurun, tetapi yang mendapat nilai antara 65-75 naik, atau meningkat $61 \%$. Sedangkan pada Siklus II peserta didik yang mendapat nilai tes akhir dalam kategori:

1. Kurang adalah 0 peserta didik.

2. Cukup adalah 4 peserta didik.

3. Baik adalah 9 peserta didik.

4. Baik sekali adalah 13 peserta didik.

Pada siklus II peserta didik yang tuntas ada 22 atau $84 \%$.

Berdasarkan perolehan ketiga hasil ulangan harian baik dari Pra Siklus, Siklus I dan Siklus II dapat disimpulkan bahwa model make a match picture signifikan terhadap upaya peningkatan motivasi dan prestasi belajar siswa. Indikator keberhasilan dari penerapan model make a match picture adalah:

Tabel 3. Indikator Keberhasilan motivasi /aktifitas Peserta Didik

\begin{tabular}{lcc}
\hline \multicolumn{1}{c}{ Aspek } & Siklus 1 & Siklus 2 \\
\hline Target Aktifitas Peserta Didik & 76 & 100 \\
\hline Perolehan & 88 & 100 \\
\hline
\end{tabular}

Tabel 4. Indikator Keberhasilan Pemahaman Peserta Didik 
gulawentah: Jurnal Studi Sosial

Volume 2 Nomor 1 Juli 2017 hal 22-28

Avaliable online at http://e-journal.unipma.ac.id/index.php/gulawentah

\begin{tabular}{lcc}
\hline \multicolumn{1}{c}{ Aspek } & Siklus 1 & Siklus 2 \\
\hline Target Hasil Pemahaman Peserta Didik & $76 \%$ & $80 \%$ \\
\hline Perolehan & $61 \%$ & $84 \%$ \\
\hline
\end{tabular}

Sedangkan kendala dan solusi Model Make A match Picture pada Materi IPS Tentang Kolonialisme di Indonesia ada siklus I hasil yang diperoleh ada peningakatan dari kategori cukup lebih baik walaupun belum mencapai ketuntasan lebih dari $27 \%$ dan rata-rata nilai masih banyak yang kurang menggembirakan. Kemudian peneliti mencoba memperbaiki teknik dengan tetap menggunakan model make a match picture tetapi merevisi lagi dengan langkah-langkah sebagai berikut: 1). Mengulang kembali permainan kartu agar pesetta didik semakin berpengalaman dalam mencari pasangan kartunya. Karena dalam siklus I masih ada yang belum tepat dan lama dalam mencari pasangan kartunya. Wajar jika hasil pemahamannya belum menggembirakan peserta didik masih dalam taraf menggali informasi belum begitu memahami. Tetapi peserta didik tertarik dan semangat ingin mengulang kembali permainan ini sampai benar tepat dan cepat dalam siklus II, 2). Menambah kartu berpasangan lagi (materi lanjutan) untuk membantu mempermudah siswa memecahkan masalahnya meningkatkan imajinasi dan memperkaya wawasan).

\section{Kesimpulan}

Berdasarkan masalah, hipotesis tindakan, serta temuan hasil dari pelaksanaan penelitian, maka dapatlah disimpulkan bahwa penerapan model pembelajaran make a match picture dapat meningkatkan aktifitas/motivasi dan pemahaman belajarnya dalam pembelajaran perkembangan kolonialisme di Indonesia.

\section{Daftar Pustaka}

Dimyati dan Mudjiono, (2015). Belajar \& Pembelajaran. Kerjasama Departemen Pendidikan \& Kebudayaan dengan Penerbit Rineka Cipta. Jakarta, PT Asdi Mahasatya.

Sanjaya, W. (2015). Penelitian tindakan Kelas. Jakarta, Prenadamedia Group

Qonita Alya, (2009), Kamus Bahasa Indonesia untuk Pendidikan Dasar, Anggota IKAPI-PT Indahjaya Adipratama

Sardiman A.M., Endang M, Dyah R Suryo, (2006). Khazanah Ilmu Pengetahuan Sosial 1. Solo, PT Tiga Serangkai Pustaka Mandiri.

Marwati Djoned Poesponegoro, Nugroho Notosusanto (Cetakan ke-5, 1984) Sejarah Nasional Indonesia III, IV Departemen Pendidikan dan Kebudayaan, PN Balai Pustaka

Sardiman A.M., Endang Mulyani, Dyah Respati Suryo, (2006). Khazanah Ilmu Pengetahuan Sosial 1. Solo, PT Tiga Serangkai Pustaka Mandiri. 